\title{
Perbedaan Pengetahuan dan Sikap Deteksi Dini Diabetes Melitus Sebelum dan Sesudah Diberikan Promosi Kesehatan di Wilayah Kerja Puskesmas Pasar Rebo
}

\author{
Nuril Fajrin Nafiati Estu Putri, Putri Permatasari \\ Program Studi S1 Kesehatan Masyarakat, Fakultas Ilmu Kesehatan \\ Universitas Pembangunan Nasional Veteran Jakarta
}

\begin{abstract}
Abstrak
Latar belakang: Diabetes Melitus merupakan suatu kondisi kronis yang terjadi ketika ada peningkatan kadar glukosa dalam darah karena tubuh tidak dapat menghasilkan hormon insulin yang cukup atau menggunakan insulin secara efektif. Diabetes Melitus dapat dicegah dengan Deteksi Dini Diabetes Melitus. Studi pendahuluan di wilayah kerja Puskesmas Pasar Rebo diperoleh masih rendahnya pengetahuan masyarakat tentang Diabetes Melitus dan presepsi yang salah tentang tandatanda awal Diabetes Melitus. Tujuan penelitian untuk melihat perbedaan pengetahuan dan sikap tentang Deteksi Dini Diabetes Melitus sebelum dan sesudah diberikan promosi kesehatan di wilayah kerja Puskesmas Pasar Rebo.
\end{abstract}

Metode: Desain penelitian menggunakan desain pre experiment dengan rancangan one group pretest posttest. Sampel pada penelitian sebanyak 42 sampel dan menggunakan instrumen berupa kuesioner mengenai pengetahuan dan sikap tentang Deteksi Dini Diabetes Melitus. Media yang digunakan adalah powerpoint dan leaflet. Analisis data menggunakan Uji Wilcoxon.

Hasil: Hasil penelitian diketahui p-value pengetahuan sebelum dan sesudah diberikan promosi kesehatan 0,000 $(<0,05)$. Dan p-value sikap sebelum dan sesudah diberikan promosi kesehatan $0,000(<0,05)$.

Kesimpulan: Terdapat perbedaan pengetahuan dan sikap tentang Deteksi Dini Diabetes Melitus sebelum dan sesudah diberikan promosi kesehatan di wilayah kerja Puskesmas Pasar Rebo. Saran peneliti yaitu promosi kesehatan tentang Deteksi Dini Diabetes Melitus perlu dilakukan pada masyarakat yang berisiko.

Kata Kunci: Deteksi Dini, Diabetes Melitus, Promosi Kesehatan

\section{Pre-Post Health Promotion to Knowledge and Attitude in Diabetes Melitus Early Detection in Pasar Rebo Health Center}

\begin{abstract}
Background: Diabetes Melitus is one of the problems that occurs when there is an increase in insulin levels in the body that cannot produce enough insulin or use insulin effectively. Diabetes Melitus can be prevented by Early Detection of Diabetes Melitus. A preliminary study in the work area of Pasar Rebo Health Center found that there was still a low level of public knowledge about Diabetes Melitus and a wrong perception about the early signs of Diabetes Melitus. The purpose of the study was to see differences in knowledge and attitudes about Early Detection of Diabetes Melitus before and after being given health promotion in the work area of Pasar Rebo Health Center.

Methods: The study design used a pre-experimental design by designing one group of posttest pretest. The samples in the study were 42 samples and used an instrument containing a questionnaire about the knowledge and attitudes about Early Detection of Diabetes Melitus. The media used are powerpoint and leaflets. Data analysis using the Wilcoxon Test.

Result: The results of the study revealed p-value knowledge before and after being given a health promotion was 0,000 (<0.05). And the p-value attitude before and after being given a health promotion was $0,000(<0.05)$.

Conclusion: There are differences in knowledge and attitudes about Early Detection of Diabetes Mellitus before and after being given health promotion in the work area of Pasar Rebo Health Center. Researcher's suggestion is that health promotion about Early Detection of Diabetes Mellitus is necessary for people at risk.
\end{abstract}

Keywords: Early Detection, Diabetes Melitus, Health Promotion

\footnotetext{
Alamat korespondensi:

Nuril Fajrin Nafiati Estu Putri

Fakultas Ilmu Kesehatan, Universitas Pembangunan

Nasional Veteran Jakarta, J1. Raya Limo, Depok

Email: nurilfajrinep@yahoo.com
} 


\section{PENDAHULUAN}

Penyebab kematian hampir $70 \%$ di dunia merupakan penyakit tidak menular (PTM). PTM adalah penyakit kronis yang tidak dapat ditularkan dari individu ke individu lainnya. PTM diantaranya adalah penyakit paru obstruktif kronis, jantung, stroke, kanker dan diabetes melitus ${ }^{4}$. Diabetes Melitus merupakan keadaan kronis yang terjadi karena adanya kadar gula yang tinggi dalam darah ketika tubuh tidak mampu menghasilkan hormon insulin yang cukup atau menggunakan insulin secara efektif ${ }^{8}$. Pada tahun 2014, diperkirakan 422 juta orang dewasa berusia 18 tahun di dunia menderita Diabetes Melitus dengan prevalensi 8,5\% di antara populasi orang dewasa. Prevalensi Diabetes Melitus terus meningkat dan tumbuh paling cepat di negara-negara berpenghasilan rendah dan menengah ${ }^{1}$.

Proporsi Diabetes Melitus Tipe 2 yang tidak terdiagnosis sangat bervariasi, tinjauan terbaru terhadap data dari tujuh negara menemukan bahwa antara $24 \%$ dan $62 \%$ orang dengan Diabetes tidak terdiagnosis dan tidak diobati. Diperlukan pendekatan multisektoral untuk mengurangi prevalensi faktor risiko Diabetes Melitus yang dapat dimodifikasi seperti kelebihan berat badan, obesitas, fisik tidak aktif dan diet yang tidak sehat. Kombinasi kebijakan fiskal, legislasi, perubahan lingkungan dan meningkatkan kesadaran akan risiko kesehatan paling baik untuk mempromosikan diet dan aktivitas fisik. Diabetes Melitus dapat ditunda atau dicegah pada orang yang kelebihan berat badan dan memiliki gangguan toleransi glukosa $(\mathrm{IGT})^{1}$. Pentingnya intervensi gaya hidup yang menggabungkan diet dan aktivitas fisik untuk mencegah diabetes pada kelompok populasi berisiko ${ }^{2}$.

Federasi Diabetes Internasional (IDF) mendorong keluarga untuk mempelajari lebih lanjut tentang tanda-tanda peringatan Diabetes Melitus. Penelitian yang dilakukan oleh IDF pada tahun 2018 menemukan bahwa orang tua akan berjuang untuk menemukan penyakit serius pada anak-anak mereka sendiri. Meskipun sebagian besar orang yang disurvei memiliki anggota keluarga yang menderita Diabetes Melitus, empat dari lima orang tua akan mengalami kesulitan mengenali tanda-tanda gejala Diabetes Melitus. Satu dari tiga individu tidak dapat menemukan tanda-tanda gejala Diabetes Melitus sama sekali. Temuan ini menggarisbawahi perlunya pendidikan dan kesadaran untuk membantu orang menemukan tanda-tanda gejala Diabetes Melitus sejak dini.
Kurangnya pengetahuan tentang Diabetes Melitus menunjukkan bahwa melihat tandatanda gejala Diabetes Melitus tidak hanya masalah bagi orang tua, tetapi merupakan masalah yang berdampak pada masyarakat. Hal ini merupakan masalah utama, karena tandatanda gejala yang lebih ringan pada Diabetes Melitus tipe 2 bertanggung jawab untuk sekitar 90\% dari semua kasus Diabetes Melitus ${ }^{3}$.

Puskesmas Pasar Rebo merupakan puskesmas peringkat kedua terbanyak dalam rekapitulasi kunjungan Diabetes Melitus di Jakarta Timur dengan jumlah sebesar 20.878 kunjungan ${ }^{4}$. Pada Puskesmas Pasar Rebo kasus Diabetes Melitus menduduki posisi kelima pada sepuluh penyakit terbanyak tahun 2018 yakni sebesar 7.982 kasus. Puskesmas Pasar Rebo memiliki target skrining usia produktif yang disesuaikan dengan sasaran proyeksi penduduk di wilayah Kecamatan Pasar Rebo yaitu 123.609 orang. Namun, hanya $18.81 \%$ masyarakat usia produktif di-wilayah-kerja PuskesmasKecamatan-Pasar Rebo-yang sudah dilakukan skrining kesehatannya yaitu 23.247 orang $^{4}$. Hal ini belum sesuai dengan Peraturan Menteri Kesehatan RI Nomor 43 Tahun 2016 tentang Standar Pelayanan Minimal Bidang Kesehatan, yang menyebutkan bahwa Pemerintah-DaerahKabupaten/Kota wajib memberikan-skrining kesehatan-sesuai standar-pada warga Negara usia 15-59 tahun di-wilayah-kerjanya dalam kurun-waktu satu-tahun dengan target capaian $100 \%$. Salah satu pelayanan skrining-kesehatan masyarakat yang berusia 15-59 tahun yaitu mendeteksi dini kemungkinan terjadi penyakit Diabetes Melitus menggunakan tes cepat glukosa darah yang dapat dilakukan minimal satu tahun sekali ${ }^{7}$.

Sejalan dengan permasalahan diatas, salah satu upaya meningkatkan pengetahuan dan sikap adalah dengan promosi kesehatan. Hasil penelitian yang dilakukan-oleh-Pancawati (2016) menunjukkan bahwa pengetahuan masyarakat tentang Diabetes Melitus 39.30\% dipengaruhi oleh pendidikan masyarakat dalam kesehatan masyarakat dan informasi tentang Diabetes Melitus yang pernah diterima oleh masyarakat ${ }^{8}$. Berdasarkan latar belakang tersebut, penulis tertarik untuk melakukan penelitian mengenai perbedaan pengetahuan dan sikap tentang deteksi dini Diabetes Melitus sebelum-dan-sesudah diberikan promosi kesehatan di wilayah-kerja Puskesmas Pasar Rebo Jakarta-Timur. 


\section{METODE}

Penelitian ini menggunakan desain Preeksperiment one group pretest posttest Penelitian dilakukan di wilayah kerja Puskesmas Pasar Rebo Jakarta Timur pada bulan Maret hingga bulan Juni 2019. Populasi pada penelitian ini yaitu masyarakat usia produktif berusia 15-59 tahun di wilayah kerja Puskesmas Pasar Rebo Jakarta Timur. Penentuan jumlah sampel yang diperlukan menggunakan Rumus Lemeshow sebanyak 42 sampel dengan teknik pengambilan purposive sampling. kriteria pemilihan sampel sebagai responden sebagai berikut: (1) Responden berusia > 15 tahun, (2) Responden belum menderita Diabetes Melitus,

(3) Responden belum mendapatkan penyuluhan kesehatan Deteksi Dini Diabetes Melitus, (4) Responden bersedia menjadi reponden penelitian. Hasil uji statistik dianalisis dengan uji normalitas Kolmogorov-smirnov dan uji Wilcoxon.

\section{HASIL}

\section{Analisis Univariat}

Berdasarkan hasil analisis univariat pada variabel umur menunjukkan bahwa pada responden dengan interval umur 15-44 tahun menunjukkan jumlah terbanyak yaitu 34 responden $(81 \%)$. Pada variabel jenis kelamin menunjukkan perempuan dengan jumlah terbanyak yaitu 30 responden $(71,4 \%)$. Pada variabel pendidikan menunjukkan bahwa jumlah terbanyak terdapat pada responden dengan tingkat pendidikan yang ditamatkan SMA yaitu sebanyak 22 responden $(52,4 \%)$. Pada variabel pekerjaan menunjukkan bahwa sebagian besar responden tidak bekerja yaitu sebanyak 36 responden $(85,7 \%)$.

Tabel 1. Distribusi Frekuensi Karakteristik Masyarakat Menurut Usia Di Wilayah KerjaPuskesmas Pasar Rebo

\begin{tabular}{lccc}
\hline & Karakteristik & Frekuensi & $\begin{array}{c}\text { Presentase } \\
(\boldsymbol{\%})\end{array}$ \\
\cline { 3 - 4 } Umur & $15-44$ tahun & 34 & 81 \\
& $\geq 45$ tahun & 8 & 19 \\
& & 42 & 100 \\
\hline Jenis & Laki-Laki & 12 & 28,6 \\
Kelamin & Perempuan & 30 & 71,4 \\
& & 42 & 100 \\
Pendidikan & SD & 1 & \\
& SMP & 14 & 33,4 \\
& SMA & 22 & 52,4 \\
& PT & 5 & 11,9 \\
& & 42 & 100 \\
\hline Pekerjaan & Tidak Bekerja & 36 & 85,7 \\
& Bekerja & 6 & 14,3 \\
& & 42 & 100 \\
\hline
\end{tabular}

Diketahui bahwa sebelum responden diberikan penyuluhan tentang Deteksi Dini Diabetes Melitus $85,7 \%$ responden memiliki pengetahuan kurang, 9,5\% responden memiliki pengetahuan sedang, dan $4,8 \%$ responden memiliki pengetahuan baik. Setelah responden diberikan penyuluhan tentang Deteksi Dini Diabetes Melitus, 2,4\% responden memiliki pengetahuan kurang, 21,4\% responden memiliki pengetahuan sedang, dan $76,2 \%$ responden memiliki pengetahuan baik. Diketahui bahwa sebelum responden diberikan penyuluhan tentang Deteksi Dini Diabetes Melitus, 31\% responden memiliki sikap negatif dan 69\% responden memiliki sikap positif. Setelah responden diberikan penyuluhan tentang Deteksi Dini Diabetes Melitus, 0\% responden memiliki sikap negatif dan $100 \%$ responden memiliki sikap positif.

\begin{tabular}{lcccc}
$\begin{array}{l}\text { Tabel 2. Distribusi Pengetahuan Dan Sikap } \\
\text { Masyarakat Di Wilayah Kerja Puskesmas } \\
\end{array}$ & $\begin{array}{l}\text { Pasar Rebo } \\
\text { Partest }\end{array}$ \\
\hline \multirow{2}{*}{ Pengetahuan } & \multicolumn{2}{c}{ Pretest } & \multicolumn{2}{c}{ Posttes } \\
Baik & $\mathrm{n}$ & $\%$ & $\mathrm{n}$ & $\%$ \\
\cline { 2 - 5 } Sedang & 2 & 4,8 & 32 & 76,2 \\
Kurang & 4 & 9,5 & 9 & 21,4 \\
\hline Total & 36 & 85,7 & 1 & 2,4 \\
\hline Sikap & 42 & 100 & 42 & 100 \\
Positif & \multicolumn{2}{c}{ Pretest } & \multicolumn{2}{c}{ Posttest } \\
Negatif & $\mathrm{n}$ & $\%$ & $\mathrm{n}$ & $\%$ \\
\hline Total & 29 & 69 & 42 & 100 \\
& 13 & 31 & 0 & 0 \\
\hline
\end{tabular}

\section{Analisis Bivariat}

Tabel 3. Uji Normalitas Data (Kolmogorov Smirnov)

\begin{tabular}{|c|c|c|}
\hline Hasil & $p$-value & Hasil \\
\hline $\begin{array}{l}\text { Pretest } \\
\text { Pengetahuan }\end{array}$ & 0,023 & Tidak Normal \\
\hline $\begin{array}{l}\text { Posttest } \\
\text { Pengetahuan }\end{array}$ & 0,005 & Tidak Normal \\
\hline Pretest Sikap & $\underline{0,001}$ & Tidak Normal \\
\hline Posttest Sikap & $\underline{0,041}$ & $\underline{\text { Tidak Normal }}$ \\
\hline
\end{tabular}

Setelah dilakukan uji satu sampel Kolmogorov Smirnov dapat dilihat pada tabel bahwa p-value pada pengetahuan dan sikap lebih kecil dari 0,05 dapat dikatakan bahwa data tidak terdistribusi dengan normal. 
Tabel 4. Uji Wilcoxon Tingkat Pengetahuan dan Sikap

\begin{tabular}{llcc}
\hline No. & Variabel & Nilai $\mathrm{p}$ & Keterangan \\
\hline 1. & Pengetahuan & 0.000 & Ada perbedaan \\
2. & Sikap & 0.000 & Ada perbedaan \\
\hline
\end{tabular}

Berdasarkan Tabel 4 dapat diketahui bahwa hasil uji statistik variabel pengetahuan menggunakan uji Wilcoxon diperoleh nilai $\mathrm{p}$ sebesar $0,000(<0,05)$, yang menunjukan bahwa terdapat perbedaan pengetahuan tentang deteksi dini Diabetes Melitus sebelum-dan-sesudah diberikan promosi kesehatan di wilayah-kerja Puskesmas Pasar Rebo Jakarta-Timur. Hasil uji statistik variabel sikap menggunakan uji Wilcoxon diperoleh nilai $\mathrm{p}$ (value) sebesar 0,000 $(<0,05)$, yang menunjukan bahwa terdapat perbedaan sikap tentang deteksi dini Diabetes Melitus sebelum-dan-sesudah diberikan promosi kesehatan di wilayah-kerja Puskesmas Pasar Rebo Jakarta-Timur.

\section{PEMBAHASAN \\ Pengetahuan}

Hasil penelitian menunjukkan nilai signifikansi antara pengetahuan sebelum dan pengetahuan sesudah dilakukan promosi kesehatan sangat signifikan yaitu nilai p-value $0,000<0,05$. Sehingga dapat dikatakan terdapat ada perbedaan pengetahuan sebelum dan sesudah diberikan promosi kesehatan tentang Deteksi Dini Diabetes Melitus di wilayah kerja Puskesmas Pasar Rebo. Menurut Notoadmojo (2007) menjelaskan bahwa pendidikan memiliki salah satu tujuan yaitu untuk mengembangkan dan meningkatkan pengetahuan, sehingga semakin tinggi tingkat pengetahuan seseorang maka semakin banyak pengetahuan yang diperoleh. Dari variabel tingkat pendidikan sebagian besar responden di wilayah kerja Puskesmas Pasar Rebo merupakan lulusan SMA. Notoadmojo (2007) juga menjelaskan bahwa umur juga mempengaruhi seseorang untuk memperoleh pengetahuan, dikarenakan semakin dewasa umur seseorng maka semakin tinggi ilmu dan pengetahuannya ${ }^{16}$.

Penelitian ini sejalan dengan (Pancawati dan Santi, 2016) yang menunjukkan hasil perbedaan pengetahuan sebelum dan sesudah diberikan pendidikan kesehatan dari data kelompok kon trol hasil $\mathrm{Z}$ hitung -2.781 dengan asymp.sig sebesar 0.005 (asymp.sig < 0,05) dan pada kelompok ekperimen hasil $\mathrm{Z}$ hitung -3.930 dengan asymp.sig 0.000 (asymp.sig $<0,05)^{14}$.
Perbedaan hasil kelompok ekperimen dan kelompok kontrol dengan melakukan uji beda hasil didapatkan $\mathrm{Z}$ hitung -2.761 dengan asymp.sig 0.006 (asymp.sig < 0,05). Sehingga dapat disimpulkan bahwa ada pengaruh pendidikan kesehatan terhadap pengetahuan deteksi dini diabetes pada masyarakat di Pedukuhan Ngemplak Karang Jati Kelurahan Sinduadi Mlati Sleman Yogyakarta.

\section{Sikap}

Hasil penelitian menunjukkan nilai signifikansi antara sikap sebelum dan pengetahuan sesudah dilakukan promosi kesehatan sangat signifikan yaitu nilai $\mathrm{p}$-value $0,000<0,05$. Sehingga dapat dikatakan terdapat ada perbedaan sikap sebelum dan sesudah diberikan promosi kesehatan tentang Deteksi Dini Diabetes Melitus di wilayah kerja Puskesmas Pasar Rebo. Menurut Allport terdapat tiga komponen sikap meliputi komponen kognitif, yaitu komponen yang tersusun atas dasar pengetahuan atau informasi yang dimiliki oleh seseorang mengenai objek sikap $^{12}$. Komponen afektif, yaitu berhubungan dengan rasa senang dan tidak senang sehingga bersifat evaluative yang berhubungan erat dengan nilai kebudayaan dan system nilai yang dimiliki. Komponen konasi, yaitu kesiapan seseorang untuk bertingkah laku yang berhubungan dengan objek sikap ${ }^{9}$. Notoatmodjo juga menjelaskan bahwa seseorang yang terpapar informasi mengenai suatu topik tertentu akan mempengaruhi stimulusnya dan akan mempengaruhi sikap subjek itu sendiri, dari pada orang yang tidak terpapar oleh informasi ${ }^{9}$.

Hasil penelitian ini sejalan dengan penelitian sebelumnya yang dilakukan oleh (Siswanto, Kamba dan Aminah, 2016) menunjukkan bahwa sikap responden saat pretest adalah sebesar $88,9 \%$ bersikap positif/mendukung, setelah dilakukan intervensi terjadi peningkatan yang mendukung/positif sebesar $94,4 \%{ }^{15}$. Peningkatan sikap positif ini merupakan dampak dari bertambahnya pengetahuan pasien mengenai diabetes dan kesadaran akan pentingnya memperhatikan dan menjaga kadar glukosa darah. Peningkatan sikap positif merupakan dampak dari bertambahnya pengetahuan pasien mengenai diabetes dan kesadaran akan pentingnya memperhatikan dan menjaga kadar glukosa darah. Sikap seseorang dipengaruhi oleh faktor internal yaitu faktor psikologis dan fisiologis serta faktor eksternal berupa intervensi yang datang dari luar individu, misalnya berupa pendidikan, pelatihan dan 
penyuluhan. Perubahan sikap dipengaruhi sejauh mana isi komunikasi atau rangsangan diperhatikan, dipahami dan diterima sehingga memberi respon positif. Selain itu, pembentukkan sikap tidaklah mudah karena tidak dapat lepas dari adanya faktor yang mempengaruhi responden seperti pengalaman pribadi, kebudayaan, media massa serta faktor emosi dari dalam individu ${ }^{15}$.

\section{KESIMPULAN}

Dapat disimpulkan bahwa pengetahuan dengan kategori baik mengalami kenaikan sebesar $71,4 \%$ dan untuk kategori sedang mengalami kenaikan sebesar $11,9 \%$ sedangkan kategori kurang mengalami penurunan sebesar $83,3 \%$. Sikap dengan kategori positif mengalami kenaikan sebesar $31 \%$ dan untuk kategori negatif mengalami kenaikan sebesar $31 \%$. Hasil uji Wilcoxon pada pengetahuan menunjukkan hasil p-value $(0,000)$ lebih kecil dari 0,05 dapat disimpulkan terdapat perbedaan pengetahuan tentang Deteksi Dini Diabetes Melitus sebelum dan sesudah diberikan promosi kesehatan di wilayah kerja Puskesmas Pasar Rebo. Hasil uji Wilcoxon pada sikap menunjukkan hasil p-value $(0,000)$ lebih kecil dari 0,05 dapat disimpulkan terdapat perbedaan sikap tentang Deteksi Dini Diabetes Melitus sebelum dan sesudah diberikan promosi kesehatan di wilayah kerja Puskesmas Pasar Rebo.

Saran yang dapat peneliti berikan setelah diadakannya penelitian ini antara lain yaitu memberikan promosi kesehatan secara berkala dan merata mengenai Deteksi Dini Diabetes Melitus kepada masyarakat usia produktif yang belum terdiagnosis sehingga skrinning usia produktif dan pencegahan penyakit Diabetes Melitus dapat berjalan maksimal.

\section{DAFTAR PUSTAKA}

1. WHO (2016) Global Report On Diabetes 2016, World Health Organization. France: WHO Press. doi: 10.1128/AAC.03728-14.

2. Alouki, K. et al. (2016) "Lifestyle Interventions to Prevent Type 2 Diabetes: A Systematic Review of Economic Evaluation Studies," Journal of Diabetes Research, 2016, hal. 1-14. doi: 10.1155/2016/2159890.

3. Menteri Kesehatan RI (2016) Peraturan Menteri Kesehatan Republik Indonesia Nomor 43 Tahun 2016 Tentang Standar Pelayanan Minimal Bidang Kesehatan. Indonesia.
4. Menteri Kesehatan RI (2017) Profil

Kesehatan Indonesia 2017. Jakarta: Kementerian Kesehatan RI. Tersedia pada:

http://www.depkes.go.id/resources/dow nload/pusdatin/profil-kesehatanindonesia/Profil-Kesehatan-Indonesiatahun-2017.pdf.

5. Sudinkes Jakarta Timur, K. J. T. (2019) Laporan Tahunan Program Pencegahan Dan Pengendalian Penyakit Tidak Menular Suku Dinas Kesehatan Jakarta Timur. Jakarta Timur.

6. Profil Kesehatan Puskesmas Pasar Rebo, K. J. T. (2019) Profil Kesehatan Kecamatan Pasar Rebo Tahun 2018. Jakarta Timur.

7. Anggraini, N. R. F., Hariyanto, T. dan Warsono (2018) "Perbedaan Tingkat Pengetahuan Tentang Diabetes Mellitus (DM) Tipe II Sebelum Dan Sesudah Diberikan Edukasi Dengan Media Audio Visual Pada Penderita Diabetes Mellitus Tipe II Di Dusun Sentong Desa Karangduren Kecamatan Pakisaji Kabupaten Malang," 3(Dm), hal. 492500.

8. IDF (2017) IDF Diabetes Atlas Eighth Edition 2017. doi: http://dx.doi. org/10.1016/S0140-6736(16)31679-8.

9. IDF (2018) Diabetes Concerns Every Family. Tersedia pada: https://www.worlddiabetesday.org/about -wdd/wdd-2018-19.html (Diakses: 14 April 2019).

10. Maria, D., S, T. C. dan Martiningsih, W. (2014) "Perubahan Persepsi Remaja Setelah Diberikan Pendidikan Kesehatan Menggunakan Media Audio Video Tentang Faktor Risiko Diabetes Mellitus Tipe 2," 1(2). doi: 10.26699/jnk.v1i2.ART.p123-128.

11. Mutoharoh (2017) Pengaruh Pendidikan Kesehatan terhadap Tingkat Pengetahuan tentang Penyakit Diabetes Mellitus pada Penderita Diabetes Mellitus Tipe 2 di Desa Ngadiwarno Sukorejo Kendal. Universitas Islam Negeri Syarif Hidayatullah Jakarta. Tersedia pada: http://repository.uinjkt.ac.id/dspace/bitst ream/123456789/36737/1/MutoharohFKIK.pdf.

12. Notoatmodjo, S. (2012) Promosi Kesehatan Dan Perilaku Kesehatan. Jakarta: Rineka Cipta. 
13. Notoatmodjo, S. (2014) Ilmu Perilaku Kesehatan. Jakarta: PT Rineka Cipta.

14. Pancawati, N. L. P. S. A. dan Santi, D. (2016) "Pengaruh Pendidikan Kesehatan Terhadap Pengetahuan Deteksi Dini DM Pada Masyarakat Di Pedukuhan Ngemplak Karang Jati Kelurahan Sinduadi Mlati Sleman Yogyakarta," Jurnal Keperawatan Respati, III. Tersedia pada: http://nursingjurnal.respati.ac.id/index.p hp/JKRY/article/view/171.
15. Siswanto, Kamba, I. dan Aminah, S. (2016) "Perbedaan Pengetahuan Dan Sikap Pasien Diabetes Mellitus Rawat Inap Rumah Sakit Islam Samarinda Sebelum Dan Sesudah Konseling Gizi Dengan Menggunakan Media Audiovisual," Jurnal Ilmiah Manuntung, 2(1), hal. 8-14. Tersedia pada: https://jurnal.akfarsam.ac.id/index.php/ji m akfarsam/article/download/39/38/.

16. Notoatmodjo, S. 2007. Promosi Kesehatan danIlmu Perilaku. Jakarta: Rineka Cipta. 